\title{
Statyba
}

\section{INVESTIGATION OF THE ACCURACY IN LABORATORY SOUND INSULATION MEASUREMENTS}

\section{A. Jagniatinskis \& B. Fiks}

To cite this article: A. Jagniatinskis \& B. Fiks (2000) INVESTIGATION OF THE ACCURACY IN LABORATORY SOUND INSULATION MEASUREMENTS, Statyba, 6:3, 202-205, DOI: 10.1080/13921525.2000.10531587

To link to this article: https://doi.org/10.1080/13921525.2000.10531587

进 Published online: 26 Jul 2012.

Submit your article to this journal $₫$

Џ Article views: 64

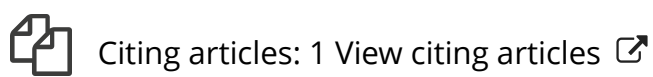




\title{
INVESTIGATION OF THE ACCURACY IN LABORATORY SOUND INSULATION MEASUREMENTS
}

\author{
A. Jagniatinskis, B. Fiks \\ Institute of Thermal Insulation
}

\section{Introduction}

Airborne noise insulation is an important parameter for set aspiration level for acoustics quality of construction materials and buildings elements. Sound insulation of building elements is frequency dependent and is represented by sound reduction index $R$ which is normally determined from series sound level difference measurements in connected reverberation rooms and calculations from the equation $[1-3]$ :

$$
R=L_{1}-L_{2}+10 \lg \frac{S T}{0.16 l^{\circ}}
$$

where $L_{1}, L_{2}$ are measured mean sound pressure levels in source room and receiving room respectively, $\mathrm{dB} ; S$ is area of the test specimen, $\mathrm{m}^{2} ; V$ is volume of the receiving room, $\mathrm{m}^{3} ; T$ is reverberation time in the receiving room, s.

Determination of the sound insulation for partitions, windows and doors is specified in various foreign standards [4-7]. These standards impose strong restrictions on the shape and volume of reverberation room, acoustical field diffusibility in the room and on the accuracy of $R$ value determination. Always there are difficulties in obtaining good accuracy of results. As far as the measurements carried out in the diffused sound field are concerned, statistical methods are used to estimate the test accuracy. General requirements of main foreign standards relating to the accuracy and conditions of measurements are listed in Table 1. It can be concluded from this table that there are some differences in these data and for factitious with higher requirements for test room volumes we have less strong requirements for precision.

\section{Description of test facility}

We use facilities with following parameters for measurements: the volume of source and receiving rooms are $70 \mathrm{~m}^{3}$ and $100 \mathrm{~m}^{3}$ respectively: $1 / 3$ octave frequency

band of interest is $100-3150 \mathrm{~Hz}$. For tests measurements are used 6 or 12 microphone positions in every room, up to 22 series of reverberation time measurements (6 registrations in every series) in receiving room. From Table 1 we can see that volumes of rooms for frequencies below $160 \mathrm{~Hz}$ are significantly smaller than it is required in Australian and USA standards and are in accordance with European and Russian standards.

Let's show, using statistical estimations of experimental data, that measurements under European standard requirements in these test rooms are valid and sufficiently precise. Also, we will obtain the necessary number of microphone positions for determination sound pressure levels $L_{1}$ and $L_{2}$ and number of reverberation time $T$ measurements. which bring desirable precision in onethird octave frequency band.

\section{Statistical estimations}

If values $L_{1}, L_{2}$, and $T$ in equation (1) are random and independent, an estimation of error $\Delta R$ of value $R$ in equation (1) may be expressed as follows:

$$
\Delta R^{2}=\Delta L^{2}+\frac{18,49}{T^{2}} \Delta T^{2},
$$

where $\Delta L$ is error of value $L=L_{1}-L_{2} ; \Delta T$ is error of reverberation time $T$ measurements.

The validity of next statistical estimations was provided by series of tests. Experiment conditions did not differ from those of a usual laboratory test. The number of microphone positions in every test room was 12 (so we get 144 values of difference $L$ ), and number of reverberation time, $T$ measurements in low frequency bands was up to 130. Estimations of probability distributions of $L$ and $T$ random values obtained from experimental data for some frequency bands are shown in Fig 1. 
Overview of different standards for sound reduction index determination

\begin{tabular}{|c|c|c|c|c|}
\hline & USA (E90-90) & Australia (AS1191-85) & $\begin{array}{c}\text { Russia (GOST } \\
27296-87 \text { ) }\end{array}$ & $\begin{array}{c}\text { European Union } \\
\text { (LST EN ISO140- } \\
\text { 3:1999) }\end{array}$ \\
\hline $\begin{array}{l}\text { Frequency range of } \\
\text { interest in } 1 / 3 \text { octave } \\
\text { band. } \mathrm{Hz}\end{array}$ & $125-4000$ & $100-5000$ & $100-3150$ & $100-5000$ \\
\hline Test room volume, $\mathrm{m}^{3}$ & $\begin{array}{c}80 \text { and } \\
125(<125 \mathrm{~Hz})\end{array}$ & $\begin{array}{c}100 \text { and } \\
163(100 \mathrm{~Hz})\end{array}$ & 50 & 50 \\
\hline $\begin{array}{l}\text { Accuracy in frequency } \\
\text { band, dB }\end{array}$ & $\begin{array}{l}\text { Sta } \\
\text { 3: } 125,160 \mathrm{~Hz} \\
\text { 2: } 200,250 \mathrm{~Hz} \\
\text { I: } 315-4000 \mathrm{~Hz}\end{array}$ & $\begin{array}{l}\text { deviation } \\
\text { 3,7: } 100 \mathrm{~Hz} \\
3.5: 125 \mathrm{~Hz} \\
3,3 ; 160 \mathrm{~Hz} \\
3,0 ; 200 \mathrm{~Hz} \\
2,5: 250 \mathrm{~Hz} \\
2,0: 315 \mathrm{~Hz} \\
1,6: 400 \mathrm{~Hz} \\
1,3 ; 500 \mathrm{~Hz} \\
1,1: 630-5000 \mathrm{~Hz}\end{array}$ & $\begin{array}{l}\text { Re } \\
\text { 3; } 100,200 \mathrm{~Hz} \\
2: 250 \mathrm{~Hz} \\
\text { 1: } 315-500 \mathrm{~Hz} \\
2: 1600-1250 \mathrm{~Hz} \\
2: 3150 \mathrm{~Hz}\end{array}$ & $\begin{array}{l}\text { bility } \\
4,5: 100 \mathrm{~Hz} \\
4,0 ; 125 \mathrm{~Hz} \\
3,5 ; 160,200 \mathrm{~Hz} \\
2,5 ; 250,315 \mathrm{~Hz} \\
2,0: 400,500 \mathrm{~Hz} \\
1.5: 630-3150 \mathrm{~Hz}\end{array}$ \\
\hline $\begin{array}{l}\text { Recommended num- } \\
\text { ber of microphone } \\
\text { positions }\end{array}$ & - & 3 & 6 & 5 \\
\hline
\end{tabular}

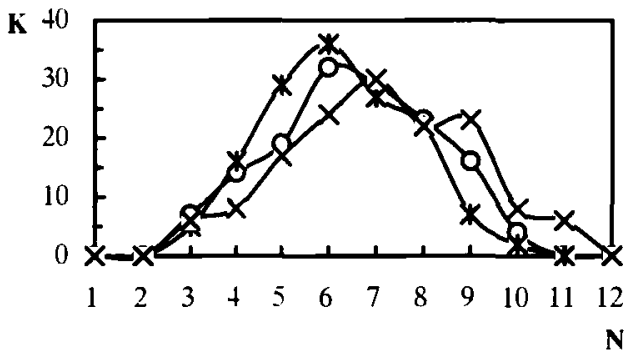

a)

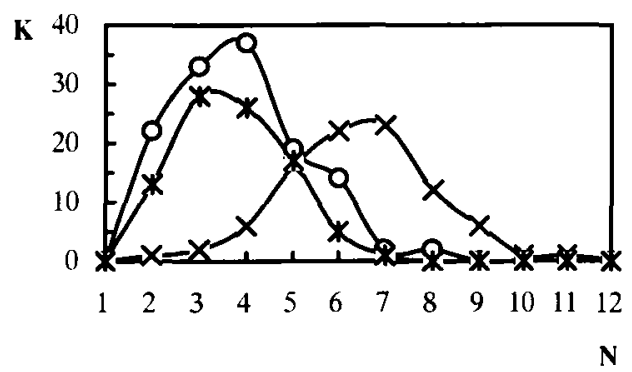

b)

Fig 1. Experimental distribution densities: a) for values $L$ in frequency bands: $0-100 \mathrm{~Hz} ; *-800 \mathrm{~Hz}: \times-3150 \mathrm{~Hz}$ and b) for values $T$ in frequency bands: $0-100 \mathrm{~Hz}: \times-400 \mathrm{~Hz} ; *-800 \mathrm{~Hz}$, where $N$ is number of intervals and $K$ is quantity of hitting for random values $L$ or $T$ in the corresponding interval

We can see from Fig 1 that the distribution of random values $L$ and $T$ correspond to a normal distribution shape, what was expected for diffuse acoustical field conditions. Quantitatively it may be tested by the Hi-square criterion for statistical hypothesis verification [8]. Achieved significance levels are illustrated in Fig 2 obtained by comparing distributions of measurement data with normal distribution. Conclusion from Fig 2 follows that significance levels of random values of $L$ and $T$ distributions densities are large enough, and it shows their proximity to the normal distribution density in one-third octave frequency bands.

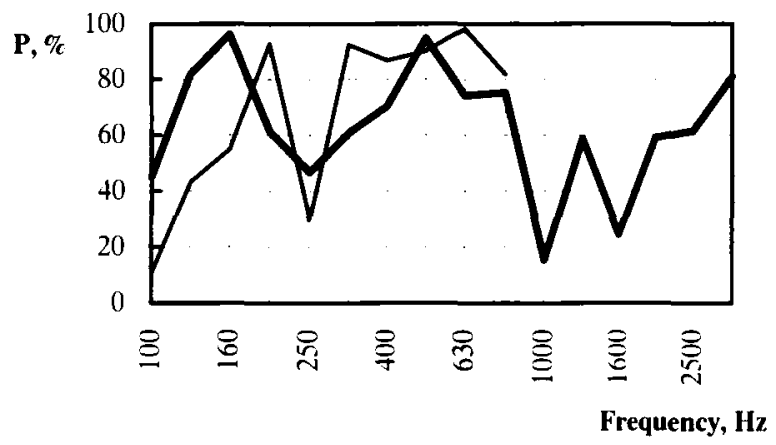

Fig 2. Significance levels $P$ obtained by comparing the experimental distributions with normal distribution in $1 / 3$ octave bands for values $L(-)$ and $T(-)$ respectively 


\section{The preciseness of sound reduction index determi- nation}

For estimating errors $\Delta L$ and $\Delta T$ from experimental data we use confidence intervals, based on Student's distribution [8]:

$$
P\left\{|\Delta X|<s_{x} t\left(\gamma, n_{x}-1\right) / n_{x}^{1} 2\right\}=\gamma,
$$

where $\Delta \mathrm{X}$ is mean deviation of measurement value $X$ from true value; $s_{x}$ is estimated standard deviation of $X$ value; $n_{x}$ is number of $X$ value determinations (measurements): $t\left(\gamma, n_{x}-1\right)$ is Student's $t$-distribution value with $n_{x}-1$ freedom levels and significance level $\gamma$; $X \in\{L, T, R\}$.

Formulae (2), taking into account (3), are expressed as follows:

$$
\begin{aligned}
& |\Delta R|<\left[s_{L}^{2} / n_{L} t^{2}\left(\gamma, n_{x}-1\right)+\frac{18,49}{\bar{T}^{2}} \times\right. \\
& \left.\times s_{T}^{2} / n_{T} t^{2}\left(\gamma, n_{T}-1\right)\right]^{2},
\end{aligned}
$$

where $\bar{T}$ is mean value of reverberation time, defined in one-third octave frequency bands.

In accordance with valid standards, it is assumed that $\gamma=95 \%$. From equation (4) we can calculate the repeatability curves in 1/3 octave frequency bands for various number of $L$ and $T$ measurements. In Fig 3 these calculated curves are shown in comparison with the repeatability of the table. Note that the repeatability values $r$ for USA and Australian standards are recalculated from expression $r=\sqrt{2 \Delta R}$ (because the repeatability is determined as difference of two following measurements of value $R$ ).

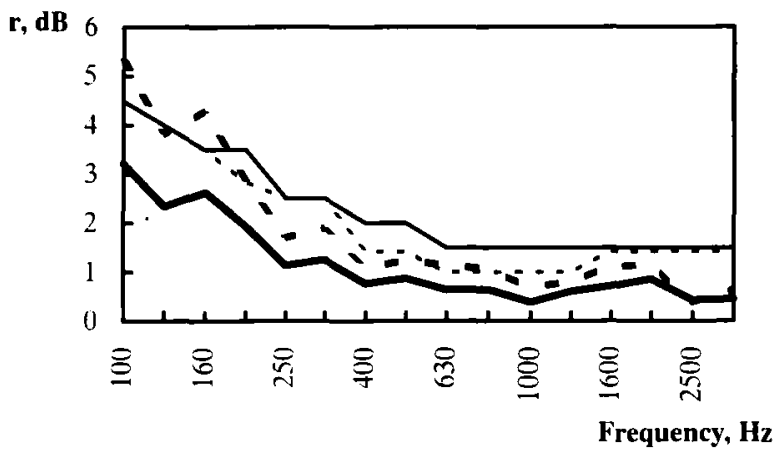

Fig 3. Repeatability values of sound reduction index $R$ obtained from experimental data: for $n_{L}=12$ curve denoted by ' - line: for $n_{L}=6$ - by ' $--^{-}$and taken from standards, listed in Table 1: European - denoted by '.-." line: common, with minimum repeatability - by '-' line
The obtained results are shown in Fig 3. To achieve the desirable accuracy in accordance with standard requirements [4-7] it is sufficient to carry out measurements of sound pressure levels in 6 microphone positions in every test room for $1 / 3$ octave bands above $200 \mathrm{~Hz}$ and - in 12 positions for $100 \mathrm{~Hz}, 125 \mathrm{~Hz}$ and $160 \mathrm{~Hz} 1 / 3 \mathrm{oc}$ tave bands. It is sufficient to determine reverberation time from one series of measurements with 6 registrations $(6$ measurements).

Note that the mean value of $R$ in accidence with here mentioned standards is determined on the base of energy mean of measured sound pressure levels [4-7], but all statistical estimations in these standards are based on arithmetic mean value. For this reason all statistical estimations and the confidence interval (4) are not symmetrical. This bias $\Delta$ may be estimated. Examine the difference between arithmetic and energy means, which is expressed as follows:

$$
\Delta=1 / n \cdot \sum L_{i}-10 \cdot \lg \left(1 / n \cdot \sum \cdot 10^{L_{i}} 10\right)
$$

where $n$ is number of measurements: $i=1, \ldots, n$.

Using not difficult transformations and the expansion of function $10^{x}$ in Taylor's series we can obtain the sufficiently precise estimation of $\Delta$ :

$$
\Delta=-10 \cdot \lg \left[1+(n-1) / n \cdot 0.027 \cdot \sigma^{2}\right]
$$

where $\sigma^{2}$ is dispersion of measured value $L$. Estimation (6) may be very important in practice for correction of the confidence interval of measured values. Usually the magnitude of this correction for low frequency octave bands is $0,8-1,0 \mathrm{~dB}$ and for high frequency octave bands is about $0,1 \mathrm{~dB}$.

\section{Conclusions}

Experimental investigations show a sufficient precision in sound reduction index measurements of construction materials and buildings elements in our reverberation rooms. It is proved statistically that the acoustical field produced in these rooms is diffuse. Also. the method of quantitative estimation of diffusibility is proposed. The given expressions allow to estimate more carefully the accuracy of sound reduction index determination from the measured data. 


\section{References}

1. Снижение шума методами звукоизоляции / Под ред. В. И. Заборова. М.: Стройиздат. 1973. 144 с.

2. И. И. Боголепов. Промышленная звукоизоляция. Л: Судостроение. 1986. $368 \mathrm{c}$.

3. A. Cops, G. Vermeir. Progress in Building Acoustics // Noise/News International. March 1995, Vol 3, No 1. p. 1025.

4. ISO 140-3:1995. Acoustics - Measurement of sound insulation in buildings and of building elements. Part 3. Laboratory measurements of airborne sound insulation of building elements.

5. AS 1191-1985. Acoustics - Method for laboratory measurement of airborne sound transmission loss of building partitions.

6. ASTM E90-90. Standard test method for laboratory measurement of airborne sound transmission loss of building partitions.

7. ГОСТ 27296-87. Защита от шума в строительстве. Звукоизоляция ограждающих конструкций. Методы измерений. М.: Издательство стандартов. 1987.

8. J. Kruopis. Matematinè statistika. Vilnius: Mokslas. 1993. 411 p.

lteikta 19991220

\section{LABORATORINIU GARSO IZOLIAVIMO MATAVIMU TIKSLUMO TYRIMAI}

\section{A. Jagniatinskis, B. Fiks}

\section{Santrauka}

Vienas iš svarbesnių statybinių medžiagu ir statinių elementụ parametru yra oro garso izoliavimas. Statybinių elementų garso izoliavimo koeficiento matavima reglamentuoja ivairiu Šaliu standartai. Juose nurodyti griežti reikalavimai bandymo kameros tinkamumui bei matavimu tikslumui nustatyti. Ivairiuose standartuose šie reikalavimai yra skirtingi (žr. 1 lentelę).

Šio straipsnio tikslas yra parodyti, kaip nustatyti bandymo kameros tinkamuma. bei apibréžti garso slègio lygiu ir aidejimo trukmès matavimų kieki. kad būtų pasiektas reikalaujamas matavimu tikslumas visose trečdalio oktavos dažnių juostose.

Garso izoliavimo koeficientas $R$ yra nustatomas pagal (1) formulę. išmatavus garso slègio lygius siunčiamojo ir priimamojo garso kamerose $L_{1}$ ir $L_{2}$ ir aidèjimo trukmę $T$ priimamojo garso kameroje. Bandant buvo naudojamos $100 \mathrm{~m}^{3}$ (siunčiamojo garso) ir $70 \mathrm{~m}^{3}$ (priimamojo garso) aidejimo kameros. atitinkančios Europos standartu reikalavimus. Matuojant bandymo kamerose buvo sukuriamas difuzinis garso laukas. Nuo jo difuziškumo lygio priklauso matavimu tikslumas. Bandymu rezultatai ivertinami remiantis statistine analize.
Darant prielaida. kad atsitiktinių dydžių $L_{1}, L_{2}, T$ tikimybiniai pasiskirstymai atitinka normalųii (difuziškumo sąlyga) ir yra nepriklausomi, gauta garso izoliavimo koeficiento nustatymo paklaidu juertinimo formulè (2). Tam. kad būtų patvirtintos daromos prielaidos bei nustatyti kiti matavimo parametrai, buvo atliekami tiriamieji matavimai, panaudojant iki 12 mikrofonu vietu ir iki 22 seriju ( 130 registracijų) aidejjimo trukmés matavimu. Nustatyta. kad atsitiktiniu dydžiu $L=L_{1}-$ $L_{2}$ ir $T$ pasiskirstymo tankiai arti normaliajam (1 pav.). 2 pav. pateikti reikšmingumo lygmenys, kai tikrinama hipoteż del atsitiktiniu dydžiu $L$ ir $T$ pasiskirstymo tankių atitikties normaliajam pasiskirstymo tankiui (pagal Hi-kvadrato kriterijų) visose trečdalio oktavos dažniu juostose. Daroma išvada. kad. norint atsitiktiniam dydžiui $R$ nustatyti pasikliautinųjų intervalu ribas. galima taikyti Stjudento pasiskirstymą (žr. (3) ir (4) formules).

Pagal nustatytus su pasikliovimo lygmeniu $\mathrm{g}=95 \%$ garso izoliavimo koeticiento paklaidos $\mathrm{D} R$ verčių ivertinimus gautos bandymu matavimu kartojimosi vertes visose trečdalio oktavos dažnių juostose (3 pav.). Iš 3 pav. matyti. kad. norint gauti pageidaujama tiksluma. remiantis standartu reikalavimais [4-7]. pakanka išmatuoti garso slègio lygius $L_{1}$ ir $L_{2}$ 6-iose mikrofono vietose. kai dažnių juostos viršija $200 \mathrm{~Hz}$. ir 12-oje mikrofono vietų. kai dažnių juostos esti mažiau kaip $160 \mathrm{~Hz}$ o aidejjimo trukmę pakanka nustatyti pagal viena matavimo seriją su 6iomis registracijomis.

Pastebeta kad garso izoliavimo koeficientas nustatomas taikant garso slègio vidurkio ivertinimus pagal energini vidurki. o jo tikslumui ivertinti imamas aritmetinis vidurkis. Dèl tos priežasties pasikliautinuju intervalu ribu vertès pasislinks tam tikra verte. Gautas gana tikslus pasislinkimo vertès ivertinimas (6) tarp matematinio ir energinio vidurkio. Tai yra svarbu, norint nustatyti garso izoliavimo koeficiento verčių patikslinimą.

Aleksandras JAGNIATINSKIS. Doctor. Head of Acoustic Laboratory. Institute of Thermal Insulation. Linkmenu g. 28. LT-2600 Vilnius. Lithuania. E-mail: aljagn@pub.osf.It.

Doctor (technical sciences. 1985). Author of more than 50 reports and papers. Research interests: acoustical measurements, building acoustics and protection against noise.

Boris FIKS. Doctor. Senior Research Fellow. Institute of Thermal Insulation, Acoustic Laboratory, Linkmeny g. 28. LT2600 Vilnius, Lithuania.

Doctor (technical sciences, 1985). Author of more than 30 reports and papers. Research interests: signal and data processing in acoustics and electroacoustics, acoustical measurements. 